\title{
The pluralism of European fundamental rights law
}

\section{Tuori, Kaarlo}

Edward Edgar

2017-07

Tuori , K 2017 , The pluralism of European fundamental rights law . in S Douglas-Scott \& N Hatzis (eds), Research Handbook on EU Law and Human Rights. Researchs Handbooks in European Law , Edward Edgar, Cheltenham , pp. 35-57 . https://doi.org/10.4337/9781782546405.00011

http://hdl.handle.net/10138/309084

https://doi.org/10.4337/9781782546405.00011

unspecified

acceptedVersion

Downloaded from Helda, University of Helsinki institutional repository.

This is an electronic reprint of the original article.

This reprint may differ from the original in pagination and typographic detail.

Please cite the original version. 
This is a draft chapter. The final version is available in Research Handbook on EU Law and Human Rights edited by S. Douglas-Scott, \& N. Hatzis, published in 2017, Edward Elgar Publishing Ltd http://dx.doi.org/10.4337/9781782546405.00011

The material cannot be used for any other purpose without further permission of the publisher, and is for private use only. 
[fresh page][cn]2. [ct]The pluralism of European fundamental rights law [au]Kaarlo Tuori

\section{[a]1. THE FRAMEWORK: LEGAL PLURALISM AND PERSPECTIVISM}

\section{[b]1.1 Polycentricity, Diversity and Pluralism}

European constitutional space - the geographical and social setting for European constitutional law - is a crowded space, in both the normative and institutional respect. It is occupied not only by state constitutional orders, watched over and implemented by state bodies of constitutional review, but also by two transnational constitutional orders, each supported by a constitutional court of its own. Many observers have seen in the situation prevailing in the European constitutional space a clear case of legal or, to be more specific, constitutional pluralism. But what, exactly, do we mean by legal pluralism and constitutional pluralism as its sub-species? Let me start with some conceptual remarks and clarifications.

First, legal pluralism should be distinguished from what in Scandinavian debates has been called polycentricity of law. 'Polycentricity' refers to important developments in the doctrine of legal sources, which determines who is allowed to participate in the continuous discourse specifying the contents of the legal order and what weight the respective contributions carry. 'Polycentricity' connotes a multiplication of sources of law; the fact that new participants have been granted access to the discourse where the ever changing content of the legal order is determined. ${ }^{1}$ The focus of 'polycentricity' is on trends within a single legal order or system; it evokes a plurality of legal sources and not of legal orders or systems.

Second, a conceptual distinction should be made between legal diversity and legal pluralism. Pluralism is not identical to but a special case of diversity. 'Legal diversity' refers to the mere coexistence of a plurality of legal orders or systems, without any implication of either harmonious or conflictual relations among them.

\footnotetext{
${ }^{1}$ Henrik Zahle, 'The polycentricity of the law or the importance of legal pluralism for legal dogmatics' in Hanne Petersen and Henrik Zahle (eds), Legal Polycentricity: Consequences of Pluralism in Law (Farnham: Ashgate 1995) 185.
} 
Thus, the black box model which, according to William Twining, has underpinned much of modern legal theory depicts legal diversity in terms of self-contained and selfsufficient normative and institutional boxes. ${ }^{2}$ Legal diversity turns into legal pluralism when state law's exclusive jurisdiction is challenged; when the legal space of a state is transformed into a hybrid space $e^{3}$ with plural claims of authority.

Legal pluralism comes in two guises: as pluralism of either legal orders or legal systems, or, in other words, normative or systemic pluralism. The distinction between the two variants of legal pluralism is based on the distinction between two aspects of law. On the one hand, law is a symbolic-normative phenomenon, a legal order. On the other hand, it consists of specific social practices - legal practices - where the legal order is produced and reproduced. Legal practices take place in a particular institutional setting: law-making in parliament and government, adjudication in courts and legal scholarship at law faculties, to enumerate the primary practices of modern law. In my conceptual scheme, 'legal system' covers both of the law's two dimensions: the legal order and institutionally framed legal practices. ${ }^{4}$

In a pluralism of legal orders (normative pluralism), more than one legal order claims authority in the same legal space; that is, the same geographically delineated social space as the setting for law. Such a situation challenges not only the hierarchical view of the Kelsenian-Hartian variant of legal positivism but also the exclusivity of state law. Yet, the challenge need not be fatal, and state law may still retain its dominance. This is the case when state law defines the conditions for the authority and applicability of non-state law and when enforcement of the latter, too, falls to state courts. ${ }^{5}$ In turn, pluralism of legal systems (systemic pluralism) contests the exclusivity of not only the state legal order but of state legal institutions and practices as well. This occurs when non-state law, claiming authority in the territory of a state, possesses its own court-like, law-enforcing bodies. Evidently, this form of legal pluralism constitutes the gravest threat to the state-sovereigntist premises of the black box model.

The concept of legal pluralism is a contribution of legal anthropologists. Yet, present legal pluralism is to a large extent a product of the fairly recent rise of

\footnotetext{
${ }^{2}$ William Twining, Globalisation and Legal Theory (Evanston, Il: Northwestern University Press 2000).

${ }^{3}$ Paul Schiff Berman, 'Global legal pluralism' (2007) 80 S Cal L Rev 1155.

${ }^{4}$ I have developed a general view of law in my Critical Legal Positivism (Farnham: Ashgate 2002) and Ratio and Voluntas (Farnham: Ashgate 2011).

${ }^{5}$ See Ralf Michaels' discussion of the alternatives for state law to acknowledge the significance of nonstate law. Ralf Michaels, 'The re-state-ment of non-state law: The state, choice of law, and the challenge from global legal pluralism’ (2005) 51Wayne L Rev 1209.
} 
transnational law. Transnational law, of which EU law is perhaps the most conspicuous epitome, has dealt the final deathblow to the black box model. Transnational law is law beyond the dichotomy of national and international law; it cannot be compressed into the compartments of the black-box model. In the black box model, legal systems and the reach of their respective claims of authority are differentiated along territorial criteria; within its territory, the claim to authority of the state legal system is universal and exclusive. It is universal in the sense of covering all substantive fields of regulation, and it is exclusive in the sense of not recognising any rival legal authority. By contrast, transnational law follows, not territorial, but functional or substantive criteria of differentiation. Its claim to authority is not universal in its scope but always limited to specific substantive fields. Yet, transnational law contests state law's claim to both exclusivity and universality. Clashes arising from contradictory principles of attribution of legal authority seem inescapable: transnational law's substantively limited claims contradict state law's universal and exclusive claim. Rival legal orders or systems are competing for authority in the same legal space; a hybrid legal space, to use again the term coined by Paul Schiff Berman.

In the hybrid European constitutional space, diversity has taken the decisive step into pluralism. Three fundamental rights orders claim authority, with two partly overlapping transnational orders contesting the exclusivity of national fundamental rights law. Each fundamental rights order is watched over by a distinct review mechanism, topped by, respectively, a national constitutional or supreme court, the European court of Human Rights (ECtHR) and the Court of Justice of the European Union (CJEU). What we can observe is not only normative but systemic pluralism, too.

By contrast, the constellation among national constitutional orders does not amount to normative or systemic pluralism but remains 'simple' diversity; as a rule, member state fundamental rights orders do not claim authority within the legal space of other member states. However, the EU law principle of mutual recognition entails that national legal acts have legal effects in other member states, too, and attach a hint of pluralism to the horizontal relations among member state legal systems. Still, strictly speaking, here the pluralistic, potentially conflictual relationship prevails between EU law and the national law of the member state under the obligation drawn from the principle of mutual recognition, and only indirectly between the two member state legal systems. 
The example of mutual recognition shows that even 'simple' legal diversity as such can become an issue for EU law. Member states may attach qualifications to recognising legal acts of other member states, similar to those that condition their acceptance of the primacy of EU law. More generally, overcoming problems which legal diversity in Europe creates for the functioning of the internal market and especially for free movement is a major - if not the major - objective of European integration as legal integration. EU constitutional law avails itself of specific legislative instruments and doctrinal means to surmount problems which diversity is deemed to cause for integration: directly effective Treaty provisions, directly applicable regulations and harmonising directives, all of them backed up by EU law's primacy over conflicting national law. The principle of mutual recognition is the lightest weapon in this arsenal: it aims at the effects of diversity, not diversity itself.

\section{[b]1.2 Radical and Dialogical Pluralists}

Due to overlapping claims of authority, legal pluralism comes accompanied by the possibility of conflict. Hence, a conflictual approach seems a natural and legitimate choice for scholars of pluralism. This is the choice of radical pluralists who reject the very possibility of a peaceful solution to the fundamental clashes of authority latent in a hybrid legal space. Radical pluralists have been well represented in debates on European constitutional pluralism, too. Yet, radical pluralists do not monopolise the scholarly field. They are confronted by legal dialogists or dialogical pluralists who profess dialogue and striving for coherence before antagonism. ${ }^{6}$ Indeed, two sides exist to the relationship between overlapping legal orders or systems: on the one hand rivalry and conflict, and on the other hand mutual dialogue and accommodation. Arguably, dialogical pluralism and its presuppositions remain under-theorised in comparison with its radical counterpart. In the following, I try to vindicate my version of dialogism through an immanent criticism of one of the main strands of radical pluralism; namely, the Kelsenian one.

\footnotetext{
${ }^{6}$ I would include in dialogical pluralists, among others, Neil Walker, Miguel Poiares Maduro and Mattias Kumm. See Neil Walker, 'Late sovereignty in the European Union' in Neil Walker (ed.), Sovereignty in Transition (Hart Publishing 2003); Miguel Poiares Maduro, 'Europe and the constitution: What if this is as good as it gets?' in Joseph H.H. Weiler and Marlene Wind (eds), European Constitutionalism Beyond the State (Cambridge: Cambridge University Press 2003). As a synthesis see Matej Avbelj and Jan Komàrek (eds), Constitutional Pluralism in the European Union and Beyond (Oxford: Oxford University Press 2012).
} 
The Kelsenian position claims to articulate the internal perspective of legal actors. Kelsen maintains that every legal actor is bound to assume the existence of a Grundnorm which constitutes the ultimate basis of validity and cognoscibility of the legal order she is applying. Multiple interpretations exist of the nature of the Grundnorm, and Kelsen's own accounts of its role vary as well. But a Kantiantranscendental aspect, at least, is crucial to an understanding of the function of the Grundnorm in the pure theory of law. For Kelsen, the (tacit) assumption of a Grundnorm is a necessary precondition of all legal cognition and all judgments of legal validity; or, to put it in Gadamerian terms, an integral element of the Vorverständnis of legal actors.

According to the Kelsenian account, each of the conflicting legal orders is subjected to its specific Grundnorm, which establishes its normativity and crowns its hierarchical structure of authority (validity). Contests of authority are bound to receive different solutions in legal systems deferring to different Grundnorms. What we encounter is an interpretation of the inevitability of legal perspectivism: no neutral ground exists where legal orders subordinated to diverse Grundnorms could meet, but the solution to the contested issue depends on the legal order from whose perspective it is approached. Now, so Kelsenian radical pluralists argue, institutional legal actors such as judges or legislators are bound to adopt the perspective of the legal order under which the institution they serve has been established and its powers defined, and whose norms they are expected to apply and uphold. Following this line of argument, it is inevitable that - to take an example related to our present topic - member state constitutional courts assess EU law's claims of authority in light of the domestic constitution, whereas the CJEU treats EU law as an independent legal order and employs the constitutional criteria of this order. Kelsenian premises do not admit of any (legal) principle which could bridge the gulf between the perspectives of self-contained legal orders; what we have here is the black box model revisited. ${ }^{7}$

The Kelsenian position is not the only variant of radical pluralism. Another one is based on Koskenniemi's version of critical legal scholarship. Kelsenians and 'crits' might seem to be odd bedfellows. However, Koskenniemi cites with approval Kelsen's

\footnotetext{
${ }^{7}$ Neil MacCormick's path-breaking articles from the 1990s, which in fact launched the still continuing debate on constitutional pluralism, largely adhered to the Kelsenian approach. See Neil MacCormick, Questioning Sovereignty (Oxford: Oxford University Press 1999). As a representative example of the approach, see also Theodor Schilling, 'Autonomy of the Community legal order: An analysis of possible foundations’ (1996) 37 Harv Intl L J 389.
} 
statement of the twin features of solipsism and imperialism, characterising especially those nation-state legal orders which subscribe to the monist doctrine in relations between municipal and international law. At the end of the day, this avowal of affinity is perhaps not so surprising, considering that 'solipsism' and 'imperialism' are apt descriptions of Koskenniemi's portrayal of the antagonistic relations among international law regimes as well; notwithstanding the vast distance between Kelsen's and Koskenniemi's legal theoretical starting points. ${ }^{8}$ Conflicts of jurisdiction between rival legal regimes are irresolvable, not because of divergent Grundnorms, but because of divergent institutional biases and the irreconcilability of the strategic interests which the institutional actors of different regimes are pursuing; say, the CJEU, the ECtHR and national constitutional courts.

Both versions of radical pluralism are attentive to the inevitable perspectivism of law; an essential feature of all law but especially accentuated in the context of EU law. Kelsenians articulate legal perspectivism in terms of the attachment of legal actors to a particular Grundnorm, whereas for Koskenniemi the irreconcilable perspectivism derives from the irreconcilable strategic interests of legal actors and institutions in the power play of law. Both camps of radical pluralism draw extremist conclusions from legal perspectivism and, consequently, are able merely to see conflicts in the relations between diverse legal orders and systems. But another side exists to these relations, too: cross-border dialogue and striving for normative coherence. This is the aspect of our pluralist lawscape which Boaventura de Sousa Santos has caught in the concept of interlegality. In the mirror of interlegality, plural legal orders, systems or regimes do not appear as self-contained entities; they are seen as mutually overlapping and maintaining a dialogical relation with each other. ${ }^{9}$

Kelsen's pure theory of law proposes a deficient view of legal actors' Vorverständnis and the legal and constitutional culture that imbues it. Kelsen is right in stressing that a doctrine of legal sources which helps to identify valid legal norms is an essential part of this Vorverständnis. But through his leap into the transcendental, Kelsen ahistoricises historically highly variable cultural phenomena. As the debate on the increasing polycentricity of law, for instance, has shown, the doctrine of legal sources is not necessarily hierarchically structured, as Kelsen claims, nor does legal

\footnotetext{
${ }^{8}$ Martti Koskenniemi, 'International law: Constitutionalism, managerialism and the ethos of legal education' (2007) 1 Eur J Intl J 1.

${ }^{9}$ Boaventura de Sousa Santos, Toward a New Legal Common Sense (London: Butterworths 2002) 347.
} 
cultural evidence support a thesis of the law's immutable conceptual skeleton. Perhaps even more serious is Kelsen's silence on the normative elements - legal principles - in legal culture and legal actors' Vorverständnis.

Still, even in its transcendental ahistoricity and substantive arbitrariness, Kelsen's reconstruction gives us a clue as to how to perceive legal perspectivism and its impact on a pluralistic legal constellation. Kelsen maintains that the normative claims of legal speech acts are always made with reference to a specific legal order. For Kelsenians, this amounts to adherence to the Grundnorm of the legal order at issue, and this adherence accounts for the different views that the CJEU and national constitutional courts hold of the ultimate validity criteria of EU law.

Legal actors' dependence on a referential legal order should be understood in broader terms than merely as application of surface level normative material or the doctrine of legal sources determining the legal validity of that material. We should also be aware of the general role of legal culture in legal practices; the functioning of legal concepts, principles and theories as a filter through which surface level legal material is cognised and interpreted. Rejecting the Kelsenian reading of legal perspectivism does not imply denying that national courts are still in an important way bound to their national legal order. Judges in national courts have received their legal education in national universities and have accumulated their professional experience in the national judiciary; consequently, their legal pre-understanding is imbued by the national legal culture. Hence, we are entitled to assume, for instance, that judges in national courts approach and interpret EU law through their national legal culture: through the legal concepts, principles and theories inherent in that culture. And, if we regard legal culture as an integral part of the legal order - as I think we should - we can speak not only of diverse perspectives to European law but also of diverse European laws, cast in different legal-cultural moulds.

Radical pluralists shut legal orders, systems and regimes in the solipsism of their particular perspectives imposed on them by their Grundnorms or by legal actors' strategic interests. The radicals are not able to account for phenomena of interlegality or the aspect of uniformity which balances the perspectivist diversity of EU law. A cultural view of legal perspectivism can overcome these shortcomings. Differences in legal or constitutional culture do not negate the possibility of a common core in nationally differentiated traditions; a common legal or constitutional deep culture, which facilitates the interlegality evoked by Sousa Santos. 
Despite European legal cultural diversity, EU law is still by and large interpreted and applied in approximately the same way in the member states. We may have 28 diverse EU laws, impregnated by diverse national legal cultures, complemented by 'EU law-EU law' in the sense of EU law as seen from the particular perspective of EU law culture. Still these EU laws are sufficiently similar to make European integration possible. The necessary uniformity is guaranteed by European legal deep culture which nationally differentiated legal concepts, principles and doctrines manifest and specify. It bridges legal diversity and facilitates ongoing cross-border dialogue, which is such an essential feature of European interlegality.

\section{[a]2. EUROPEAN FUNDAMENTAL RIGHTS PLURALISM}

\section{[b]2.1 Lessons from Perspectivism}

As a token of legal perspectivism, every legal system defines itself its relations to other legal systems. No second-order master principle or ultimate institutional arbiter exists to guarantee the mutual compatibility of such definitions; hence the ever-present possibility of conflicts on which radical pluralists build their case.

The inexorable legal perspectivism affects how one conceives of European fundamental rights pluralism. This can be approached from the point of view of each of the overlapping and rival fundamental rights laws. Again, no normative or procedural guarantees exist for the compatibility of the way in which pluralistic legal systems conceive of their mutual relations. Yet, the legal systems occupying European constitutional space have adopted various techniques to reduce the probability of clashes, while not relinquishing their final say. In this chapter, the perspective of the European Convention on Human Rights (ECHR) will be left aside and the discussion focused on the way EU and member states' fundamental rights laws, respectively, define their mutual relationship.

In its landmark decisions in the 1960s - in particular van Gend en Loos and Costa $v$ Enel $^{10}$ - the CJEU declared Community law's independence from both (general) international law and member states' municipal law. It also specified

\footnotetext{
${ }^{10}$ Case C-26/62 Van Gend en Loos v Administratie der Belastingen [1963] ECR 1; Case C-6/64 Flaminio Costa v Enel [1964] ECR 585.
} 
Community law's relationship to member state law through the principles of direct effect and primacy. As the well-known and often-recited (hi)story tells us, especially the principle of primacy was destined to meet rather widespread resistance among member state legal actors, before it was gradually accepted. Still, the acceptance of EU law's primacy by key national legal actors, such as constitutional courts, has never been unconditional. Through constitutional provisions and the rulings of constitutional or supreme courts, member state legal systems have articulated the principles which govern their relationship to transnational, EU law. The German Constitutional Court is the most important national interlocutor of the CJEU; this justifies letting it articulate the following perspective of member state fundamental rights law. ${ }^{11}$ The German court has formulated the conditionality of EU law's primacy in terms of three types of review available to contest the constitutionality of national measures based on EU law: ultra vires review, fundamental rights review and an identity review.

Through the accessibility of ultra vires review, the Court claims ultimate Kompetenz-Kompetenz jurisdiction; the final competence to decide, for the purposes of defending the German constitution, whether a particular Union action has been taken within Union competences. The preconditions of fundamental rights review are defined through the Solange doctrine. Finally, identity review protects Germany's constitutional identity even beyond the area covered by fundamental rights review. ${ }^{12}$ These three forms of review point to the three main problem fields where EU and national fundamental rights law may clash:[bl]

- $\quad$ the extension of EU fundamental rights review with regard to national measures;

- $\quad$ the level of protection offered by EU fundamental rights law;

- $\quad$ respect for Member States' constitutional identity.[/list]

Heeding the lessons of legal perspectivism, all three fields of potential friction should be examined from the point of view of both EU and national fundamental rights law. And, as is the case with legal pluralism in general, two alternative approaches exist: one putting emphasis on latent or overt conflicts and the other on interlegality.

\footnotetext{
${ }^{11}$ Daniel Thym, 'Attack or retreat? Evolving themes and strategies of the judicial dialogue between the German Constitutional Court and the European Court of Justice' in Monica Claes and others (eds), Constitutional Conversations in Europe (Cambridge: Intersentia 2012).

${ }^{12}$ See from the quite extensive literature on the three types of review Mehrdad Payandeh, 'Constitutional review of EU Law after Honeywell: Contextualizing the relationship between the German Constitutional Court and the EU Court of Justice' (2011) 48 CML Rev 9. The emphasis in Payandeh's analysis lies on the ultra vires review.
} 


\section{[b]2.2 The Extension of EU Fundamental Rights Review}

If in the 1960s the CJEU defined through its rulings Community law's position in relation to member state and international law, the horizontal articles of the Charter attempt to achieve a similar positioning for EU fundamental rights law with regard to national law and the ECHR. Two things must be kept in mind when discussing these articles. First, the provisions of the horizontal articles cannot be detached from the doctrinal elaboration by the CJEU of fundamental rights law or (other) general principles of EU law. Second, the articles should be treated as contributions to a constitutional discourse where not only other EU bodies but member state constitutional actors, too, participate. The provisions are moves in an ongoing dialogue between EU and member state constitutional actors. ${ }^{13}$

Article 51(1) of the Charter addresses the first problem field in the relations between EU and national fundamental rights law: the applicability of EU fundamental rights law to national measures. Where EU fundamental rights law is applicable, national courts are supposed to act as instruments of EU review: in accordance with the principle of primacy, national courts are supposed to set aside national in favour of EU fundamental rights law. According to Article 51(1), the Charter is addressed to the member states when these 'are implementing Union law'.

Article 52(7) of the Charter grants the explanations relating to the Charter explicit and for EU law exceptional source value. ${ }^{14}$ The explanations concerning Article 51(1) refer to pre-Lisbon case law, implying that the Charter expression 'implementing Union law' should be assigned a meaning equivalent to 'acting in the scope of EU law' in case law on fundamental rights principles. ${ }^{15}$ This premise has been confirmed by postLisbon case law, most notably Åkerberg Fransson.

\footnotetext{
${ }^{13}$ Diverse aspects of this dialogue are discussed in the contributions in Claes and others (n 11).

${ }^{14}$ In, e.g., Aklagaren $v$ A kerberg Fransson, the CJEU explicitly invokes the explanations, Case C-617/10 ECLI:EU:C:2013:280, para 20.
}

\footnotetext{
${ }^{15}$ As regards the Member States, it follows unambiguously from the case law of the Court of Justice that the requirement to respect fundamental rights defined in the context of the Union is only binding on the member states when they act in the scope of Union law, see Case C-5/88 Wachauf v Budesamt füe Ernährung und Forstwirtschaft [1989] ECR 2609; Case C-260/89 ERT v DEP [1991] ECR I-2925; Case C-309/96 Annibaldi [1997] ECR I-7493.
} 
The pre-Lisbon case law referred to in Akerberg Fransson ${ }^{16}$ indicates that the two main situations where national measures come under EU fundamental rights review are, first, where member states are implementing an obligation imposed by EU law and, second, when they are - in a justified way - derogating from such an obligation. In the literature, implementation of EU law is sometimes further differentiated into two subcases: first, where member states are fulfilling an express mandate laid down by EU law and, second, where they act on an option provided by EU law. Akerberg Fransson took the argument in the second sub-case rather far. The CJEU considered itself competent to examine whether national legislation on tax penalties and tax evasion, applied to providing false information concerning VAT, was compatible with the ne bis in idem principle laid down in Article 50 of the Charter. The Court disregarded the fact that national legislation was not adopted for the purposes of transposing Directive 2006/112 on the common system of value added tax; ${ }^{17}$ to show the necessary connection to EU law it was sufficient that its application is designed to penalise an infringement of that directive and is therefore intended to implement the obligation imposed on the Member States by the Treaty to impose effective penalties for conduct prejudicial to the financial interests of the European Union' (paras 25-28).

Constitutional turbulence in some member states has induced proposals to stretch Union fundamental rights jurisdiction over national measures beyond the limits established by pre-Lisbon jurisprudence on fundamental rights principles and postLisbon case law on Article 51(1) of the Charter). A more liberal reading of Article 51(1), which would extend the Charter's applicability to autonomous member state action, appears to collide with formidable doctrinal obstacles. Both Article 6(1) of the Treaty on European Union (TEU) and Article 51(2) of the Charter, manifesting the principles of conferral (Article 5(3) TEU) and subsidiarity (Article 5(4) TEU) invite a strict interpretation of Article 51(1). Consequently, doctrinal support for general Union fundamental rights competence has been sought elsewhere in the Treaties. Favourite Treaty anchorages for comprehensive fundamental rights review have been provisions

\footnotetext{
16 The Court mentioned Case C-260/89 ERT [1991] ECR I-2925, para 42; Case C-299/95 Kremzow [1997] ECR I-2629, para 15; Case C-309/96 Annibaldi [2007] ECR I-7493, para 13; Case C-94/00 Roquette Frères [2002] ECR I-9011, para 25; Case C-349/07 Sopropé [2008] ECR I-10369, para 34; Case C-256/11 Dereci and Others [2011] ECR I-11315, para 72; and Case C-27/11 Vinkov v Nachalnik Administrativno-nakazatelna deynost ECLI:EU:C:2012:326, para 58.

${ }^{17}$ Council Directive (EC) 2006/112 on the common system of value added tax [2006] OJ L347/1.
} 
on European citizenship and, after Lisbon, Article 2 TEU on the value basis of the Union.

Armin von Bogdandy et al. ${ }^{18}$ argue that by attaching fundamental rights to European citizenship, judicial protection can be provided for the values enumerated in Article 2 TEU, which, the authors concede, are not justiciable as such. Judicial protection, tapping the vigilance of individuals, would complement the political mechanism set out in Article 7 TEU. As member states are expected to respect foundational values in all their activities, Union fundamental rights review would be brought to cover all member state activity, that is, purely internal domains as well.

To achieve such a result, two argumentative moves should be vindicated: first, a redefinition of EU fundamental rights as rights of European citizens and, second, attachment of fundamental rights qua citizenship rights to the values enshrined in Article 2 TEU. As regards the first move, Bogdandy et al. build on recent citizenship jurisprudence, especially Ruiz Zambrano. Here the Court ruled that Article 20 of the Treaty on the Functioning of the European Union (TFEU) on European citizenship:

[quotation] is to be interpreted as meaning that it precludes a Member State from refusing a third country national upon whom his minor children, who are European Union citizens, are dependent, a right of residence in the Member State of residence and nationality of those children, and from refusing to grant a work permit to that third country national, in so far as such decisions deprive those children of the genuine enjoyment of the substance of the rights attaching to the status of European Union citizen (emphasis added). ${ }^{19}$ [/quotation]

Bogdandy et al. draw quite far-reaching generalizing conclusions from Ruiz Zambrano. First, Ruiz Zambrano is alleged to show that European citizenship can be invoked in a member state in a purely internal situation with no cross-border elements. Second, 'the substance of the rights attaching to the status of European Union citizen' is claimed to refer to EU fundamental rights in general so that Ruiz Zambrano would have confirmed their character as citizenship rights.

The first conclusion concerning EU citizenship's relevance in purely internal situations may already need specification. However, what is more pertinent now is to

\footnotetext{
${ }^{18}$ Armin von Bogdandy et al., 'Reverse Solange - protecting the essence of fundamental rights against EU member states' (2012) 49 CML Rev 489; Daniel Sarmiento, 'The EU's constitutional core' in Alejandro Saiz Arnaiz and Carina Alcoberro Llivina (eds), National Constitutional Identity and European Integration (Cambridge: Intersentia 2013).

${ }^{19}$ Case C-34/09 Ruiz Zambrano [2011] ECR I-1177, para 45.
} 
problematise the link between citizenship and fundamental rights, allegedly forged by Ruiz Zambrano. Articles 20-23 TFEU contain explicit provisions on the rights deriving from the status of EU citizen, and the Charter includes a specific Chapter on Citizens' rights (Title V). As is well-known, the CJEU has derived auxiliary social rights from explicitly stipulated citizenship rights, in particular rights to mobility and residence. But no case law evidence exists which would point to a constitutional connection between citizenship and EU fundamental rights in general. Nothing in Ruiz Zambrano intimates that 'rights attaching to the status of European Union citizen' would cover EU fundamental rights as a whole and not only the rights explicitly derived from European citizenship in Articles 20-23 TFEU and Title V of the Charter, complemented by auxiliary social rights. Bogdandy et al. are correct in pointing out the affinity of citizenship and fundamental rights in constitutional theory and history. But this does not suffice to establish a connection between the two in EU 'surface-level' constitutional law. ${ }^{20}$ To define European citizenship in terms of fundamental rights and to claim on that ground jurisdiction for the Union in purely internal fundamental rights violations would involve a huge leap in the CJEU's incrementally built citizenship jurisprudence. It would also require surmounting doctrinal hurdles so high that its probability is very low.

The provisions and explanations concerning applicability of the Charter, which have curbed proposals to stretch the reach of EU fundamental rights review by an imaginative interpretation of Article 51(1) of the are not directly pertinent for constructions which try to find their 'institutional support' elsewhere in the Treaties; indeed, to escape these limitations is a central backdrop to reorientation of the search for solid doctrinal ground for the Union's general fundamental rights competence. But the principle of conferral, explicitly set out in Article 5(2) TEU, certainly is relevant, as is the general worry of many member states of the EU taking steps in a federal direction through the CJEU's fundamental rights jurisprudence. Proposals now under discussion do pay heed to these worries to some extent: the function of the Solange part of the proposal by von Bogdandy et al. EU fundamental rights review, grounded in citizenship, would be confined to protecting the essence of rights. This limitation would

\footnotetext{
${ }^{20}$ In its case law subsequent to Ruiz Zambrano, the CJEU has abstained from abstained from extending 'the rights attaching to the status of European Union citizen' to EU fundamental rights in general. See Case C-434/09 McCarthy [2011] ECR I-3375 and Dereci (n 16), which both invoked the issue of respect for family life.
} 
correspond to the 'substance' of citizenship rights which Ruiz Zambrano declared protected. The 'essence' of fundamental rights would also equal human rights as basic values, such as they are conceived of in Article 2 TEU. Moreover, this notion would bring reverse Solange in congruence with the doctrine of inviolability of the essence of fundamental rights; a doctrine adopted in Article 52(1) of the Charter, and adhered to by the ECtHR, as well as national systems of constitutional review.

Second, only systematic violations of the essence of fundamental rights would be justiciable. The assumption would be that member state review mechanisms are able to deal with infringements, and only if this expectation were rebutted and infringements received a systematic nature, would EU fundamental rights review be competent to interfere; hence, the term 'reverse Solange'.

The weak point in the doctrinal argument remains the connection between citizenship and fundamental rights, for which no 'institutional support' exists in either Treaty provisions or Ruiz Zambrano or other case law of the CJEU. Furthermore, in the hybrid European constitutional space, doctrinal considerations within EU law, however convincing they might be, are not enough to ground such a significant constitutional change as extension of Union fundamental rights jurisdiction to member state autonomous activity. Such a discursive move by the CJEU would still need acceptance by other main participants in European constitutional discourse, in particular national constitutional or supreme courts and the ECtHR. The German Constitutional Court has been quick to react to what it has considered threatening signs of the CJEU expanding its fundamental rights jurisdiction and to give a reminder of potential use of its ultra vires review.

In Honeywell, ${ }^{21}$ the German Constitutional Court responded to the CJEU's ruling in Mangold. ${ }^{22}$ The complainant had claimed that the CJEU in Mangold had transgressed the boundaries of interpretation of Community law in a manner which was no longer covered by the competences of the Community. In the end, the Constitutional Court found that the CJEU had not exceeded the borderline beyond which ultra vires

\footnotetext{
${ }^{21}$ BVerfG, 2 BvR 2661/106.

${ }^{22}$ Case C-144/04 Mangold [2005] ECR I-9981. The judgment dates from the pre-Lisbon time and was not based on the Charter but on Directive 2000/78/EC establishing a general framework for equal treatment in employment and occupation. The CJEU held it to be the responsibility of the national court to guarantee the full effectiveness of the general principle of non-discrimination in respect of age and to set aside any provision of national law which may conflict with Community law, even where the period prescribed for transposition of the directive had not yet expired. In the post-Lisbon Kücükdeveci, the Court confirmed prohibition of discrimination based on age as a general principle of Union law and referred as grounds to Article 21(1) of the Charter. Case C-555/07 Kü̈ukdeveci [2010] ECR I-365.
} 
review would be available. However, the Court's detailed discussion of the applicability of ultra vires review to fundamental rights case law is a clear reminder to the CJEU that its German counterpart would not approve expansion of European jurisdiction over the limits set in Article 51(1)-(2) of the Charter. Honeywell and Mangold concerned prohibition of age discrimination as a general principle of EU law. Invoking Article 51(2) of the Charter, the Constitutional Court pointed out that 'even if they guarantee the protection of fundamental rights at Union level, general principles may not expand the field of influence of Union law over and above the existing competences of the Union or indeed establish new tasks and competences' (para 78). ${ }^{23}$

Another reminder followed in early 2013. In a decision issued less than two months after the CJEU ruling in Åkerberg Fransson, the Constitutional Court held that the German 'Counter-Terrorism Database Act pursues nationally determined objectives which can affect the functioning of the legal relationships under EU law merely indirectly'. Consequently, the Court argued, 'European fundamental rights are from the outset not applicable'. The Court expressly emphasised that the CJEU's decision in A kerberg Fransson does not change this conclusion. In line with Honeywell, the Court characterised European and national fundamental rights review as a cooperative relationship. From this it inferred that Akerberg Fransson 'must not be read in a way that would view it as an apparent ultra vires act or as if it endangered the protection and enforcement of the fundamental rights in the member states in a way that questioned the identity of the Basic Law's constitutional order'. ${ }^{24}$

It is highly improbable that the CJEU would discount the German Constitutional Court's message, deliberately induce ultra vires review in member states and take the risk of an overt constitutional conflict. Furthermore, there is no reason to presume that national constitutional or supreme courts would be more receptive to general EU fundamental rights review of a reverse Solange type. ${ }^{25}$ In addition to reactions from

\footnotetext{
${ }^{23}$ See on Honeywell and its significance, Payandeh (n 12).

${ }^{24}$ BVerfG, 1 BvR 1215/07. See the Court's Press release no 31/2013 of 24 April 2013. See also the editorial comment 'Ultra vires - has the Bundesverfassungsgericht shown its teeth?' (2013) $50 \mathrm{CML}$ Rev 925.

${ }^{25}$ Interestingly enough, in its Lisbon ruling the German Constitutional Court, as if anticipating subsequent doctrinal debates, renounced reliance on Article 2 TEU as a basis for the Union's alleged Kompetenz-Kompetenz: 'As primacy by virtue of constitutional empowerment is retained, the values codified in Article 2 Lisbon TEU, whose legal character does not require clarification here, may in the case of a conflict of laws not claim primacy over the constitutional identity of the Member States, which is protected by Article 4.2 first sentence Lisbon TEU and is constitutionally safeguarded by the identity review pursuant to Article 23.1 third sentence in conjunction with Article 79.3 of the Basic Law. The values of Article 2 Lisbon TEU, which are contained in part as principles in the current Article 6.1 TEU,
} 
member state courts, the CJEU would certainly heed the likely rejoinder from Strasbourg as well. By adopting a reverse Solange doctrine, the CJEU would contest the ECtHR's position as the transnational court with general fundamental rights jurisdiction. This would most probably provoke a counter-move by the ECtHR. Radical pluralists' nightmare would come true: a fundamental conflict of authority would break out among the key judicial actors in European constitutional space.

Differing from reverse Solange, advocated by Bogdandy et al., horizontal Solange entrusts general fundamental rights review, extending to internal member state action, to the courts of other member states. If reverse Solange is intended to influence future case law, horizontal Solange is claimed to have already been confirmed by the CJEU.

Iris Canor ${ }^{26}$ grounds this claim on the CJEU's ruling in N.S. ${ }^{27}$ In this ruling, the Court first stated that the discretionary power which the Dublin II Regulation ${ }^{28}$ leaves to member states forms an integral part of the Common European Asylum System. When a member state exercises this power and decides whether or not to examine an application which is not its responsibility according to the criteria of the Regulation, it implements Union law for the purposes of Article 6 TEU and Article 51 of the Charter (paras 65-68). According to the Court, the Common European Asylum System is built on the principle of mutual confidence. The underlying assumption is that participating States observe fundamental rights and that the member states can have confidence in each other in this regard (para 78). However, the assumption is rebuttable. The system 'may, in practice, experience major operational problems in a given Member State, meaning that there is a substantial risk that asylum seekers may, when transferred to that Member State, be treated in a manner incompatible with their fundamental rights' (paras 80-81). Still, not any infringement of a fundamental right by the member state responsible suffices to prevent the transfer of an asylum seeker. Only:

[quotation]if there are substantial grounds for believing that there are systemic flaws in the asylum procedure and reception conditions for asylum applicants

\footnotetext{
do not provide the European union of integration with Kompetenz-Kompetenz, so that the principle of conferral also continues to apply in this respect.' Para 332.

${ }^{26}$ Iris Canor, 'My Brother's Keeper? Horizontal Solange: "An ever closer distrust among the peoples of Europe"' (2013) 50 CML Rev 383.

${ }^{27}$ Joined Cases C-411/10 and C-493/10 N.S. and Others ECLI:EU:C:2011:865.

${ }^{28}$ Council Regulation No 343/2003 establishing the criteria and mechanisms for determining the Member State responsible for examining an asylum application lodged in one of the Member States by a third-country national [2003] OJ L50/1.
} 
in the Member State responsible, resulting in inhuman or degrading treatment, within the meaning of Article 4 of the Charter, of asylum seekers transferred to the territory of that Member State, the transfer would be incompatible with that provision' (para 86). [/quotation]

If such grounds exist, EU fundamental rights law obliges a member state not to transfer the asylum seeker to the member state responsible.

Thus, according to N.S., EU fundamental rights law imposes on member states, including their courts, an obligation to monitor compliance with that law in other member states. Yet, the basic, though rebuttable, assumption guiding the member state action is that other member states respect the relevant fundamental rights; hence the term 'horizontal Solange'. It is important to note that EU law is the applicable law with regard to both the member state considering the transfer of an asylum seeker and the member state responsible. We are dealing with the application and observance of EU fundamental rights law in two member states and not the horizontal relation between national fundamental rights laws. The term 'horizontal Solange' is justified in the sense that a member state's authorities are monitoring another member state's fundamental rights record. But, actually, these authorities are exercising 'vertical' EU fundamental rights review.

Can one derive from N.S. a general doctrine of horizontal Solange and member states' general obligation to watch over each other's observance of EU fundamental rights? Canor answers in the affirmative. In her argument, two steps in particular would require 'institutional support' in N.S. or other CJEU case law. First, 'systemic violation of core European fundamental rights' in a member state would oblige other member states to suspend cooperation with that member state. It remains unclear what kind of cooperation this obligation would cover. Canor's focus is on member states' obligation to refuse on certain conditions cooperation stipulated by EU secondary legislation - in N.S. by Regulation 343/2003 - but she does not spell out the exact reach of horizontal Solange. Would the obligation preclude other member states from applying the EU law principle of mutual recognition, which in some fields is acknowledged in political and in others in judicial legislation? It is difficult to find in N.S. backing for a general Solange doctrine applicable to member state cooperation beyond the specific constellation under Regulation 343/2003 where a member state makes use of its discretionary power of either deciding itself an asylum application or transferring the applicant to the member state responsible. 
It is true, though, that in N.S. the CJEU invokes the more general principle of mutual confidence which implies the presumption of member states' complying with fundamental rights. One could argue that this would vindicate generalising horizontal Solange to cover at least all instances of mutual recognition underpinned by this principle. Horizontal Solange would be especially relevant in the former third-pillar area of freedom, security and justice. Still, as regards for instance the European Arrest Warrant, the CJEU has not invoked such a general doctrine but has relied on the explicit provisions of the Framework Decision on mandatory or optional non-execution of such a warrant. ${ }^{29}$ However, in the absence of such provisions, a horizontal Solange-type argument might be possible.

The other controversial argumentative step leads from EU law-related to autonomous member state action. N.S. concerned member state action and cooperation in a fundamental rights sensitive field regulated by EU law. Not only the decision making of the member state where the asylum seeker was present but also the actions or non-actions of the member state responsible which rebutted the presumption of compliance with fundamental rights were located within the scope of EU law: at issue were systematic flaws in asylum procedure and reception of asylum seekers, leading to inhuman or degrading treatment. From this, there is a long way to go to reach the conclusion that member states would have an obligation to monitor each other's general fundamental rights record, regardless of whether or not the alleged flaws are related to EU law or the cooperation at issue.

\section{[b]2.3 Level of Protection}

The second issue of possible friction between EU and member state fundamental rights law, determining the level of protection, should also be examined from both perspectives. In EU law, Article 53 of the Charter addresses the issue in relation both to member state constitutions and the ECHR. In both relations, Article 53 intimates that in its field of application, the Charter only defines the bottom line of protection:

[quotation]Nothing in this Charter shall be interpreted as restricting or adversely affecting human rights and fundamental freedoms as recognised, in their

\footnotetext{
${ }^{29}$ See Case C-396/11 Radu ECLI:EU:C:2013:39. See also Case C-306/09 I.B. [2010] ECR I-10341; and Case C-399/11 Melloni ECLI:EU:C:2013:107.
} 
respective fields of application, by Union law and international law and by international agreements to which the Union or all the Member States are party, including the European Convention for the Protection of Human Rights and Fundamental Freedoms, and by the Member States' constitutions. ${ }^{30}$ [/quotation]

Melloni has added a significant qualification to the application of Article 53 of the Charter with regard to member state fundamental rights law. The main legal issue in Melloni was whether a member state could refuse to execute a European Arrest Warrant 'in order to avoid an adverse effect on the right to a fair trial and the rights of the defence guaranteed by its constitution'. The protection offered by the national constitution exceeded the level offered by the Charter with which the Framework Decision, according to the CJEU's judgment, was in harmony. The CJEU firmly rejected the interpretation which the national court had envisaged and which would give 'general authorisation to a Member State to apply the standard of protection of fundamental rights guaranteed by its constitution when that standard is higher than that deriving from the Charter and, where necessary, to give it priority over the application of provisions of EU law' (para 56). The Court argues that the national court's reading of Article 53 'would undermine the principle of the primacy of EU law inasmuch as it would allow a Member State to disapply EU legal rules which are fully in compliance with the Charter where they infringe the fundamental rights guaranteed by that State's constitution' (para 58). The Court characterises the principle of primacy as an essential feature of EU law, which provides that 'rules of national law, even of a constitutional order, cannot be allowed to undermine the effectiveness of EU law on the territory of that State' (para 59). The Court presents a new formulation of the normative contents of Article 53:

[quotation]Article 53 of the Charter confirms that, where an EU legal act calls for national implementing measures, national authorities and courts remain free to apply national standards of protection of fundamental rights, provided that the level of protection provided for by the Charter, as interpreted by the Court, and the primacy, unity and effectiveness of EU law are not thereby compromised (para 60 - emphasis added).[/quotation]

\footnotetext{
${ }^{30}$ In addition to Article 53, the relationship between the Charter and the ECHR is governed by the interpretative principle laid down in Article 52(4): 'In so far as this Charter contains rights which correspond to rights guaranteed by the Convention for the Protection of Human Rights and Fundamental Freedoms, the meaning and scope of those rights shall be the same as those laid down by the said Convention.' However, 'this provision shall not prevent Union law providing more extensive protection'.
} 
Melloni might be labelled a special case, due to the fact that the Framework Decision includes explicit provisions on member states' rights to refuse a European Arrest Warrant and that these were expressly designed to heed fair trial concerns. However, the Court formulated its reading of Article 53 of the Charter in general terms, with the clear intention of articulating a principle with general applicability. Daniel Sarmiento portrays reference to the primacy, unity and effectiveness of EU law as an exceptional remedy; a last-resort safety measure for extraordinary situations. ${ }^{31}$ Yet, the way Melloni defines the primacy of the principle of primacy with regard to the member state right to enforce higher national standards appears to deprive Article 53 of the Charter of much of its relevance. Situations addressed by Article 53 are by definition situations of overlapping jurisdiction where the principle of primacy is relevant. Thus, one might ask, when can national fundamental rights law with a higher level of protection actually trump EU law? In his Opinion in Melloni, Advocate General Bot points to a situation where that could be the case: where the member state can invoke the EU constitutional principle of respect for member state constitutional identity (Article 4(2) TEU). ${ }^{32}$ Second, Akerberg Fransson demonstrates that in the CJEU's view the pertinence of the primacy of EU law varies, depending on the degree of discretion EU law leaves to national measures. Following Sarmiento, one could speak here of complete and partial determination by EU law. ${ }^{33}$ However, in para 29 of Melloni the Court intimates that even in situations of only partial determination, the principle of primacy may override national fundamental rights autonomy. ${ }^{34}$

A third exception to the principle of primacy may derive from the position of the ECHR in a member state legal order. If the member state at issue has incorporated the ECHR, national fundamental rights law may indirectly benefit from the provisions

\footnotetext{
${ }^{31}$ Daniel Sarmiento, 'Who's afraid of the Charter? The Court of Justice, national courts and the new framework of fundamental rights protection in Europe' (2013) 50 CML Rev 1267, 1295.

${ }^{32}$ However, according to AG Bot, this was not the situation in Melloni, and the Member State itself had conceded that its national identity was not involved. Melloni (n 29), Opinion of AG Bot, paras 139-42. ${ }^{33}$ Sarmiento (n 31) 1289.

34 '.... where a court of a Member State is called upon to review whether fundamental rights are complied with by a national provision or measure which, in a situation where action of the Member States is not entirely determined by European Union law, implements the latter for the purposes of Article 51(1) of the Charter, national authorities and courts remain free to apply national standards of protection of fundamental rights, provided that the level of protection provided for by the Charter, as interpreted by the Court, and the primacy, unity and effectiveness of European Union law are not thereby compromised'. See also on the relationship between Article 4(2) TEU and Article 53 of the Charter the analysis in Aida Torres Pérez, 'Constitutional identity and fundamental rights: The intersection between articles 4(2) TEU and 53 Charter' in Arnaiz and Llivina (n 18).
} 
of the Charter on the relationship of Charter rights with the ECHR. No principle of primacy guides this relationship, or justifies deviating from the wording of Article 53 or the interpretative principle set out in Article 52(3) of the Charter. ${ }^{35}$ Finally, member states are free to apply higher national standards when derogating from EU law; that is, in the second main situation where member states are deemed to act within the scope of EU law for the purposes of EU fundamental rights protection. ${ }^{36}$

Reverse and horizontal Solange adopt the perspective of EU fundamental rights law and are expansionist by nature: both proposals aim at extending the scope of EU review over national measures. By contrast, the original Solange embraced the point of view of the national constitution and was defensive by nature: it aimed at safeguarding national fundamental rights protection from the threat perceived to derive from the EU law principle of primacy. The Solange saga is intimately intertwined with the development of EU fundamental rights law: what, from the perspective of German constitutional law appears as the history of the Solange doctrine, tells us from the point of view of EU law about the consolidation of its fundamental rights dimension.

In Solange I, issued on 29 May 1974, ${ }^{37}$ the German Constitutional Court argued that Article 24 of the Basic Law, the then constitutional basis for transferring sovereign rights to inter-state institutions, did not authorise amending the fundamental structure of the Basic law, the basis of its identity, through the legislation of an inter-state institution. The part dealing with fundamental rights is an alienable, essential feature of the Basic Law and part of its constitutional structure. The Court pointed out that the Community still lacked 'a codified catalogue of fundamental rights, the substance of which is reliably and unambiguously fixed for the future in the same way as the substance of the Basic Law'. Consequently, the Court avowed that it would review the compatibility of Community law, relevant to the decision of a German court, in light of national fundamental rights 'as long as the integration process has not progressed so far that Community law also receives a catalogue of fundamental rights decided on by a

\footnotetext{
35 'In so far as this Charter contains rights which correspond to rights guaranteed by the Convention for the Protection of Human Rights and Fundamental Freedoms, the meaning and scope of those rights shall be the same as those laid down by the said Convention. This provision shall not prevent Union law providing more extensive protection'.

${ }^{36}$ See Nik de Boer, 'Addressing rights divergences under the Charter: Melloni' (2013) 50 CML Rev $1083,1096$.

${ }^{37}$ BVerfGE 37, 2712 BvL 52/71.
} 
parliament and of settled validity, which is adequate in comparison with the catalogue of fundamental rights contained in the Basic Law'. However, before filing a reference with the Constitutional Court, the court at issue should obtain a ruling of the ECJ in the preliminary reference procedure under Article 177 TEEC (present Article 267 TFEU).

Solange II, issued on 22 October $1986,{ }^{38}$ reaffirmed that the Basic Law does not allow conferral on international institutions of a power to encroach on the identity of the prevailing constitutional order of the Federal Republic and that fundamental rights principles are an essential part of this order. However, in Solange II the Court recounted the progress achieved in Community fundamental rights law and concluded that it could now revise the position of Solange I. The Court formulated a new Solange doctrine, with deference to EU fundamental rights review and non-application of national review as the - rebuttable - starting point. ${ }^{39}$

Since the issuance of Solange II, the fundamental rights dimension of EU law has been further consolidated, the latest stage consisting of conferral of legal effect on the Charter in Lisbon and post-Lisbon case law, with A kerberg Fransson and Melloni as important recent landmarks. The national concerns that lay behind the Solange rulings are largely a matter of the past. The principal worries of member state interlocutors in ongoing constitutional dialogue no longer relate to the general level of Union fundamental rights protection but to the two other fields of potential friction: extension of EU fundamental rights review and respect for member state constitutional identity. For member state constitutional actors, the main problems no longer derive from underdevelopment of EU law's fundamental rights dimension but, rather, EU law exceeding its legitimate limits.

\section{[b]2.4 Respect for Constitutional Identity}

\footnotetext{
${ }^{38}$ BVerfGE 73, 3392 BvR 197/83.

39 'In view of those developments it must be held that, so long as the European Communities, in particular European Court case law, generally ensure effective protection of fundamental rights as against the sovereign powers of the Communities which is to be regarded as substantially similar to the protection of fundamental rights required un-conditionally by the Basic Law, and in so far as they generally safeguard the essential content of fundamental rights, the Federal Constitutional Court will no longer exercise its jurisdiction to decide on the applicability of secondary Community legislation cited as the legal basis for any acts of German courts or authorities within the sovereign jurisdiction of the Federal Republic of Germany, and it will no longer re-view such legislation by the standard of the fundamental rights contained in the Basic Law ...'
} 
Every legal system not only defines its relations to other legal systems but also tries to defend its identity. Accordingly, member state constitutional and supreme courts have articulated their reservations concerning EU law's claim of primacy as inviolability of their constitutional identity; the justification and the exact terms may vary but the main idea is approximately the same. Again, the German Constitutional Court is a representative mouthpiece for the member state perspective. ${ }^{40}$

From the very outset, identity review and fundamental rights review have been closely connected in the jurisprudence of the German Constitutional Court. Solange I and Solange II justified fundamental rights review with reference to the preservation of German constitutional identity. In the Lisbon ruling, which includes the most detailed elaboration of identity review, protecting fundamental rights principles finds its place under this heading, too. ${ }^{41}$

In line with the dialogical development of EU fundamental rights law, national constitutional and supreme courts have held the initiative in the dialogue resulting in Lisbon in the adoption of respect for member state constitutional identity as a principle of EU constitutional law. ${ }^{42}$ Through Article 4(2) the EU constitutional legislator acknowledged the identity qualification which national constitutional actors had attached to acceptance of EU law's claim of primacy. Continuing the pluralistic constitutional discourse, the German Constitutional Court took notice of the speech act of the Union constitutional legislator. In its Lisbon ruling, the Court assigned identity

\footnotetext{
${ }^{40}$ As a brief summary of other constitutional courts' jurisprudence see Armin von Bogdandy and Stephan Schill, 'Overcoming absolute primacy: Respect for national identity under the Lisbon Treaty' (2011) 48 CML Rev 1417; Monica Claes, 'National identity: Trump card or up for negotiations' in Arnaiz and Llivina (n 18) 124. Especially on the case law of the new Central European member states see Wojciech Sadurski, "Solange, Chapter 3": Constitutional courts in Central Europe - democracy - European Union' (2008) 14 ELR 1; Joël Rideau, 'The case-law of the Polish, Hungarian and Czech Constitutional Courts on national identity and the "German model"" in Arnaiz and Llivina (n 18). As a general review of member state constitutional law relating to the EU, see Christoph Grabenwarter, 'National constitutional law relating to the European Union' in Armin von Bogdandy and Jürgen Bast (eds), Principles of European Constitutional Law, 2nd edn (Oxford/Munich: Hart Publishing/CH Beck/ 2010). ${ }^{41}$ BVerfG, 2 BvE 2/08, para 249. As a succinct presentation of the German Constitutional Court's jurisprudence on constitutional identity see Christian Tomuschat, 'The defence of national identity by the German Constitutional Court' in Arnaiz and Llivina (n 18).

${ }^{42}$ The Maastricht Treaty already contained a provision obliging the Union to respect the national identities of its Member States (article 6(4) TEU-Maastricht). Yet, as Claes, (n 40) 130, has demonstrated, the provision played but a minor role in pre-Lisbon case law. Only in Lisbon was a constitutional dimension expressly included in the national identity. According to Article 4(2) TEULisbon, 'the Union shall respect the equality of Member States before the Treaties as well as their national identities, inherent in their fundamental structures, political and constitutional, inclusive of regional and local self-government'.
} 
review the task of securing that 'the inviolable core content of the constitutional identity of the Basic Law' is respected. The Court argued that 'with progressing integration, the fundamental political and constitutional structures of sovereign Member States, which are recognised by Article 4(2) first sentence Lisbon TEU, cannot be safeguarded in any other way', and concluded that 'in this respect, the guarantee of national constitutional identity under constitutional and under Union law go hand in hand in the European legal area'. ${ }^{43}$

Thus, Article 4(2) TEU should be seen as a contribution to the ongoing dialogue between EU and member state constitutional actors. Of course, it does not by itself ensure that no future clashes over fundamental rights jurisdiction will arise; this would require an additional guarantee of the identity of the constitutional identities as interpreted by the CJEU and national constitutional actors. But no such guarantee exists. Still, through Article 4(2), the Union constitutional legislator has kept the channel for discussion open. Moreover, in two recent CJEU cases, the CJEU and its member state interlocutors have adopted a similar reading of national constitutional identity. If no guarantee for agreement exists, conflict is not inevitable, either. ${ }^{44}$

In Sayn-Wittgenstein, the CJEU 'accepted that, in the context of Austrian constitutional history, the Law on the abolition of the nobility, as an element of national identity, may be taken into consideration when a balance is struck between legitimate interests and the right of free movement of persons recognised under European Union law' (para 83). What is significant for the present discussion is that the Court expressly evoked Article 4(2) TEU (para 92). In turn, in the proceedings in Melloni Attorney General Bot and the Spanish authorities agreed that the reading of the constitutional right to fair trial, adopted by the Spanish constitutional court and requiring a right to reopen a criminal case where the defendant has been sentenced in absentia, did not bear on Spanish constitutional identity. ${ }^{45}$

\footnotetext{
${ }^{43}$ BVerfG, 2 BvE 2/08, para 240. See also para 332, where the Court states 'the constitutional identity of the Member States protected by Art 4(2) TEU and constitutionally safeguarded by the identity review'. ${ }^{44}$ A dialogical approach on the principle of respect for national constitutional identity has also been adopted by, e.g. Leonard F.M. Besselink, 'National and constitutional identity before and after Lisbon' (2010) 6 Utrecht Law Review 36, and von Bogdandy and Schill (n 40).

${ }^{45}$ Opinion of AG Bot in Melloni (n 29), paras 139-42.
} 
The CJEU's clinging to the principle of primacy in situations where a member state constitution offers a higher level of fundamental rights protection intimates that not only member states but the EU, too, keeps watch on its constitutional identity. Indeed, things could hardly be otherwise: for the EU legal system, too, guarding its constitutional identity is a precondition for preserving its independence. In Van Gend en Loos and Costa v Enel, the ECJ declared Community law's independence in two directions: with regard to member state legal systems and (general) international law. Accordingly, constitutional identity may acquire at least partly different traits when invoked vis-à-vis international law or member state law. Allan Rosas and Lorna Armati have interpreted $\mathrm{Kadi}^{46}$ as confirmation of 'a tendency discernible in earlier case law according to which the EU constitutional order consists of some core principles which may prevail over provisions of the Treaties and thus of written primary law'. ${ }^{47}$ Here the authors make specific reference to the position of the judgment that rights and duties arising from international agreements concluded before accession:

[quotation]may in no circumstances permit any challenge to the principles that form part of the very foundations of the Community legal order, one of which is the protection of fundamental rights, including the review by the Community judicature of the lawfulness of Community measures as regards their consistency with those fundamental rights' (para 304).[/quotation]

This entails that foundational principles override the provisions in Article 351 TFEU (previously Article 307 TEC) which lay down that the Treaties do not affect rights and duties arising from international agreements concluded before accession. But Kadi can be read not only as a sign of an internal hierarchy in EU constitutional law but also as an assertion of constitutional identity vis-à-vis international law: the Court assessed an EU regulation implementing a decision of the UN Security Council in light of EU fundamental rights standards.

Doubts can be raised as to whether fundamental rights principles were part of the Community's constitutional identity at the time when Community law made its declaration of independence through Van Gend en Loos and Costa v Enel. Still,

\footnotetext{
${ }^{46}$ Joined Cases C-402/05 P and C-415/05 P Kadiv Council and Commission [2008] ECR I-6351.

${ }^{47}$ Allan Rosas and Lorna Armati, EU Constitutional Law: An Introduction, 2nd edn (Oxford: Hart Publishing 2012) 54.
} 
constitutional identity is not only a relational but also a dynamic phenomenon. Subsequent development of EU fundamental rights law, culminating in explicit conferral of legal effect on the Charter in Lisbon, together with confirmation of the EU's value basis in Article 2 TEU, lend credence to the assertion in Kadi and the conclusion drawn from it by Rosas and Armati. These authors leave open what else the EU constitutional identity might include. ${ }^{48}$ With regard to member state law, the two principles which in Van Gend en Loos and Costa v Enel accompanied Community law's claim of autonomy, the principles of primacy and direct effect, certainly are an essential part of Union constitutional identity. These principles are inexorably linked to the two second-order principles which provide them with justification: namely, the efficacy and unity of EU law. Hence, the prevalence in Melloni of EU law's primacy over the member state right to apply a higher national fundamental rights standard can also be understood as the CJEU defending the EU's constitutional identity with regard to a member state. ${ }^{49}$

The CJEU's assertion of the EU's constitutional identity may give rise to a new type of conflict: a clash between Union and member state constitutional identity. The CJEU may agree with member state authorities that a particularity of national fundamental rights law forms part of the member state's constitutional identity and, hence, falls under the obligation imposed on the CJEU by Article 4(2) TEU. Yet, the CJEU might conclude that protection of Union constitutional identity overrides respect for national constitutional identity so that, for the sake of the primacy, unity and effectiveness of EU law, Union fundamental rights standards should be applied instead of national ones. Respect for member state constitutional identity may not always trump the principles included in the EU's constitutional identity.

\section{[b]2.5 Dialectic of Constitutional Diversity and Uniformity}

In the horizontal relations among member states, the recognition by EU constitutional law of national constitutional identities implies recognition of constitutional diversity as well: member states may display significant differences in their constitutional

\footnotetext{
${ }^{48}$ Sarmiento (n 18), defines the EU's constitutional core and legal identity through the three normative ideals of democracy, rights and solidarity, to which especially Articles 2-4 TEU give expression.

${ }^{49}$ See also Sarmiento (n 31) 1295, who states that 'in line with its national counterparts, Luxembourg has powerful reasons to impose its own counter-limits, whose purpose is, in the last instance and in line with previous case law, to guarantee the autonomy of EU law'.
} 
cultures, differences which are instrumental to their distinct constitutional identities. However, Treaty law manifests, not only diversity of constitutional identities, but also an assumption of common constitutional traditions. Such an assumption underlies both Article 6(3) TEU, which indicates member states' common constitutional traditions as a source of fundamental rights as general EU law principles, and Article 52(4) of the Charter, which defines the role of these traditions in the interpretation of Charter rights. Furthermore, article 2 TEU postulates a common value basis for both member state and Union fundamental rights law. The Preamble to the Charter manifests the dialectic of uniformity and diversity in clear terms. The Union is declared to be grounded in common values but, by the same token, to respect cultural diversity among member states.

The idea of the multilayered nature of law in general and constitutional law in particular illustrates how constitutional diversity and uniformity can be reconciled. Fundamental rights law can be examined at three different levels. The surface level consists of explicit constitutionally relevant normative material, such as constitutional regulations, constitutionally relevant case law and doctrinal positions presented and defended by constitutional scholars. At this level, constitutional law in force can be understood as an always temporary result of an ongoing constitutional discourse, where the principal participants are the constitutional legislature, the constitutional court(s) and other bodies of constitutional review as well as constitutional scholars. ${ }^{50}$ The surface level constitutional law is backed up by constitutional culture, which informs the Vorverständnis of constitutional actors and, thus, plays a vital role in constitutional discourse, responsible for surface-level turbulence. Distinct constitutional systems possess distinct constitutional cultures but they may still share a common core which justifies talk of constitutional deep culture. What is included in particular constitutional cultures and how the unifying deep culture is defined is always a matter of interpretation, and the interpretation is never normatively innocent. Article 2 TEU can be understood as a reading of the deep culture which is supposed to unite the constitutional cultures of the member states as well as that of the Union.

We can reverse our examination, adopt a bottom-up view and portray the multilayered nature of fundamental rights law in terms of a relation of specification. In

\footnotetext{
${ }^{50}$ In the EU, analysis of constitutional discourse is more intricate than in nation states, due to the composite character of both the constitutional legislature and the mechanism.
} 
constitutional deep culture, such as that depicted in Article 2 TEU, fundamental rights, as well as other central principles of a democratic Rechtsstaat, are present as general normative ideas. In different legal cultures, these principles are interpreted in different ways. Anglo-American legal culture perhaps emphasises liberty rights more than the Roman Germanic legal cultures of Continental Europe, where social, economic and cultural rights represent a graver threat to the unchallenged dominance of the former. Legal cultures show differences even in mechanisms for protection of rights; for example, in the division of labour between the legislature and the courts. The process of specification is brought to its end at the surface level in constitutional provisions and other regulations, court decisions and standpoints presented by constitutional scholars.

Diversity of constitutional identities is related to the differentiation of constitutional cultures in European constitutional space. In my three-level scheme, this diversity is evidently a phenomenon of the middle level, with its background in divergent national historical trajectories and experiences which for instance explain the varying emphases among fundamental rights in the member states. Diversity does not exclude resemblances in national constitutional identities and cultures; existence of common constitutional traditions as alluded to in Article 6(3) TEU and Article 52(4) of the Charter. Both particular and unifying features are supported by a common supportive constitutional deep culture, which they interpret and specify against a partly divergent and partly comparable historical backdrop. Common deep culture also makes it at least possible to arrive in the Union and the member states at compatible definitions of the reach of EU fundamental rights review, the level of protection of fundamental rights and constitutional identities. Common deep culture also facilitates such interlegality as the ongoing cross-boundary constitutional discourse in the hybrid European constitutional space; a discourse where multiple transnational and national constitutional actors participate.

Tokens of interlegality demonstrate that a discursive way exists to prevent clashes of authority the possibility of which cannot be negated under conditions of pluralism. In turn, interlegality among member states mitigates problems for EU law which otherwise would arise from the diversity of member state laws. All in all, interlegality, arising from and facilitated by common constitutional deep culture, goes a long way to compensate for lack of a second-order principle or arbiter for pacifying conflicts in European constitutional space. 